Article

\title{
How Should Staphylococcal Food Poisoning Outbreaks Be Characterized?
}

\section{Jacques-Antoine Hennekinne*, Annick Ostyn, Florence Guillier, Sabine Herbin, Anne-Laure Prufer and Sylviane Dragacci}

French Agency for Food, Environmental and Occupational Health Safety (Anses)-Food safety laboratory of Maisons-Alfort, European Union Reference Laboratory for Coagulase Positive Staphylococci, 23 avenue du Général de Gaulle, 94706 Maisons-Alfort, France;

E-Mails: annick.ostyn@anses.fr (A.O.); florence.guillier@anses.fr (F.G.); sabine.herbin@anses.fr (S.H.); anne-laure.prufer@anses.fr (A.-L.P.); sylviane.dragacci@anses.fr (S.D.)

* Author to whom correspondence should be addressed; E-Mail: Jacques-antoine.hennekinne@ anses.fr; Tel.: +331497726 24; Fax: +33149774666.

Received: 21 June 2010 / Accepted: 5 August 2010 / Published: 10 August 2010

\begin{abstract}
Staphylococcal food poisoning is one of the most common food-borne diseases and results from the ingestion of staphylococcal enterotoxins (SEs) preformed in food by enterotoxigenic strains of Staphylococcus aureus. To date, more than 20 SEs have been described: SEA to SEIV. All SEs have superantigenic activity whereas only a few have been proved to be emetic, representing a potential hazard for consumers. Characterization of staphylococcal food poisoning outbreaks (SFPOs) has considerably progressed compared to 80 years ago, when staphylococci were simply enumerated and only five enterotoxins were known for qualitative detection. Today, SFPOs can be characterized by a number of approaches, such as the identification of $S$. aureus biovars, PCR and RT-PCR methods to identify the $s e$ genes involved, immunodetection of specific SEs, and absolute quantification by mass spectrometry. An integrated gene-to-protein approach for characterizing staphylococcal food poisoning is advocated.
\end{abstract}

Keywords: staphylococcal enterotoxin; food poisoning; enzyme immunoassay; molecular tools; mass spectrometry 


\section{Coagulase-Positive Staphylococci and Staphylococcal Enterotoxins}

\subsection{Coagulase-Positive Staphylococci}

Staphylococcus is a spherical, non-sporulating, non-motile bacterium (coccus) that, when observed under the microscope, occurs in pairs, short chains or grape-like clusters. These facultative aero-anaerobic bacteria are Gram- and catalase-positive. Staphylococci are ubiquitous in the environment and can be found in the air, dust, sewage, water, environmental surfaces, humans and animals.

To date, 50 species and subspecies of staphylococci have been described according to their potential to produce coagulase. Their classification thus distinguishes between coagulase-producing strains, designated as coagulase-positive staphylococci (CPS), and non-coagulase-producing strains, called coagulase-negative staphylococci (CNS). However, only CPS strains have been clearly implicated in food poisoning incidents. Among the seven described species belonging to the CPS group (Table 1), S. aureus subsp. aureus is the main causative agent described in staphylococcal food poisoning outbreaks (SFPOs). During processing and storage, temperatures outside the range of $7-48{ }^{\circ} \mathrm{C}$ prevent the growth of $S$. aureus. However, $S$. aureus subsp. aureus strains are usually very tolerant to $\mathrm{NaCl}$ and grow well in $\mathrm{NaCl}$ concentrations of up to $10 \%$; growth is possible, although retarded, even in concentrations of up to $20 \%$.

Table 1. Genus Staphylococcus: coagulase-positive species.

\begin{tabular}{llc}
\hline \multicolumn{1}{c}{ Species } & \multicolumn{1}{c}{ Main sources } & Ref. \\
\hline S. aureus subsp. aureus & humans, animals & {$[1]$} \\
S. aureus subsp. anaerobius & sheep & {$[2]$} \\
S. intermedius & dog, horse, mink, pigeon & {$[3]$} \\
S. hyicus & pig, chicken & {$[4]$} \\
S. delphini & dolphin & {$[5]$} \\
S. schleiferi subsp. coagulans & dog (external ear) & {$[6]$} \\
S. lutrae & otter & {$[7]$} \\
\hline
\end{tabular}

\subsection{Staphylococcal Enterotoxins}

To date, 21 staphylococcal enterotoxins (SEs) and enterotoxin-like (SEl) types have been described (Table 2): enterotoxins A (SEA), B (SEB), $C_{1}\left(\mathrm{SEC}_{1}\right), \mathrm{C}_{2}\left(\mathrm{SEC}_{2}\right), \mathrm{C}_{3}\left(\mathrm{SEC}_{3}\right), \mathrm{D}$ (SED), E (SEE), G (SEG), H (SEH), I (SEI), J (SElJ)[8], K (SElK)[9], L (SEIL), M (SEIM), N (SEIN), O (SElO)[10], P (SElP)[11], Q (SElQ)[12], R (SER)[13], S (SES), T (SET)[14], U (SElU)[15], and U2 and V, which are located in an open reading frame of the enterotoxin gene cluster egc that encodes enterotoxin-like proteins [16].

Enterotoxin and enterotoxin-like proteins are globular, single polypeptides (Figure 1) with molecular weights ranging from 22 to $29 \mathrm{kDa}$. They can be encoded in prophages [17], plasmids [18] or chromosomal pathogenicity islands [19]. The currently known SEs form a group of serologically distinct, extracellular proteins that share important properties, namely: (1) the ability to cause emesis and gastroenteritis in primates; (2) superantigenicity through an unspecific activation of T lymphocytes followed by cytokine release and systemic shock [20]; (3) resistance to heat and to digestion by pepsin; and (4) structural similarities [21]. 
Table 2. Staphylococcal enterotoxin characteristics.

\begin{tabular}{|c|c|c|c|c|}
\hline $\begin{array}{l}\text { Toxin } \\
\text { type }\end{array}$ & $\begin{array}{c}\text { Molecular } \\
\text { weight (Da) }\end{array}$ & Genetic basis of SE & $\begin{array}{c}\text { Superantigenic } \\
\text { action }\end{array}$ & Emetic action \\
\hline SEA & 27,100 & Prophage & + & + \\
\hline SEB & 28,336 & $\begin{array}{c}\text { Chromosome, plasmid, } \\
\text { pathogenicity island }\end{array}$ & + & + \\
\hline $\mathrm{SEC}_{1-2-3}$ & $\approx 27,500$ & Plasmid & + & + \\
\hline SED & 26,360 & Plasmid (pIB485) & + & + \\
\hline SEE & 26,425 & Prophage & + & + \\
\hline SEG & 27,043 & $\begin{array}{l}\text { enterotoxin gene cluster } \\
(\text { egc }), \text { chromosome }\end{array}$ & + & + \\
\hline SEH & 25,210 & Transposon & + & + \\
\hline SEI & 24,928 & egc, chromosome & + & + \\
\hline SElJ & 28,565 & Plasmid (pIB485) & + & $\mathrm{nk}$ \\
\hline SEK & 25,539 & Pathogenicity island & + & nk \\
\hline SEIL & 24,593 & Pathogenicity island & + & - \\
\hline SEIM & 24,842 & $e g c$, chromosome & + & nk \\
\hline SEIN & 26,067 & $e g c$, chromosome & + & nk \\
\hline SElO & 26,777 & $e g c$, chromosome & + & nk \\
\hline SElP & 26,608 & Prophage (Sa3n) & + & $\mathrm{nk}$ \\
\hline SElQ & 25,076 & Pathogenicity island & + & - \\
\hline SER & 27,049 & Plasmid (pIB485) & + & + \\
\hline SES & 26,217 & Plasmid (pIB485) & + & + \\
\hline SET & 22,614 & Plasmid (pIB485) & + & + \\
\hline SEIU & 27,192 & $e g c$, chromosome & + & nk \\
\hline SElU $_{2}$ & 26,672 & $e g c$, chromosome & + & nk \\
\hline SEIV & 24,997 & egc, chromosome & + & nk \\
\hline
\end{tabular}

+: positive reaction; -: negative reaction; nk: not known.

Figure 1. 3D structure of SEB. Reproduced with permission from Elsevier [22].

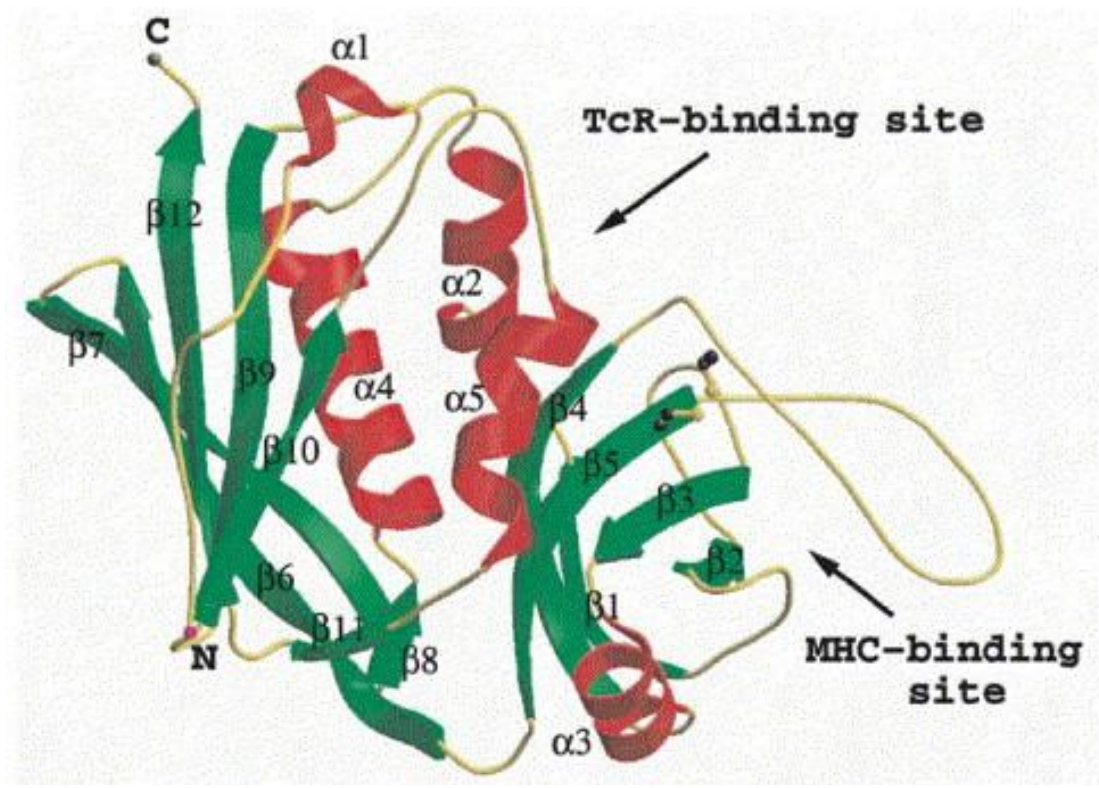




\section{SFPOs: Definition and Required Conditions for Their Occurrence (European Data)}

Due to the previously enumerated properties of CPS and SEs, staphylococcal food poisoning (SFP) is one of the most common food-borne diseases and results from the ingestion of SEs preformed in food as these SEs are produced by enterotoxigenic strains of CPS, mainly Staphylococcus aureus [23].

The incubation period and severity of symptoms depend on the amount of enterotoxins ingested and the susceptibility of each individual. Initial symptoms - nausea followed by incoercible characteristic

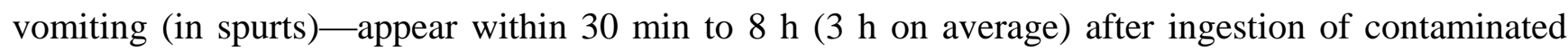
food. Other commonly described symptoms include abdominal pain, diarrhea, dizziness, shivering and general weakness sometimes associated with a moderate fever. In the most severe cases, headache, prostration and low blood pressure have been reported. In the majority of cases, recovery occurs within 24 to $48 \mathrm{~h}$ without specific treatment, while diarrhea and general weakness can last $24 \mathrm{~h}$ or longer. Death is rare, occurring primarily in those susceptible to dehydration (infants and elderly people) and in those affected by an underlying illness.

Five conditions are required to induce SFPOs: (1) a source containing enterotoxin-producing staphylococci: raw materials, healthy or infected carrier; (2) transfer of staphylococci from source to food: dirty food preparation tools due to poor hygiene practices; (3) food composition with favorable physico-chemical characteristics for $S$. aureus growth and toxinogenesis; (4) favorable temperature and sufficient time for bacterial growth and toxin production; and (5) ingestion of food containing sufficient amounts of toxin to provoke symptoms.

Most SFPOs arise due to poor hygiene practices during processing [24], cooking or distributing the food product [25]. Staphylococci are commonly found in a wide variety of mammals and birds and transfer of $S$. aureus to food has two main sources: human carriage during food processing and dairy animals in case of mastitis.

In Europe, the European Food Safety Authority [26] reported that, in 2008, bacterial toxins were involved in 525 out of 5332 notified food poisoning outbreaks $(9.8 \%)$, ranking third in pathogenicity after Salmonella spp. (35.4\%) and viruses (13.1\%). Among bacterial toxins, SEs were involved in 291 out of the 525 notified food poisoning outbreaks (55.4\%), or 5.5\% of all notified outbreaks in 2008 .

\section{Analytical Tools Used in SFPO Characterization: Pros and Cons}

Diagnosis of SFP is generally confirmed by one of the following results: (1) the recovery of at least $10^{5} \mathrm{~S}$. aureus/g from food remnants; (2) the detection of SEs in food remnants; and/or (3) the isolation of the same $S$. aureus strain from both patient and food remnants [27]. In some cases, confirmation of SFP is difficult because $S$. aureus is heat-sensitive, whereas SEs are not. Thus, in heat-treated food matrices, S. aureus may be eliminated without inactivating SEs. In such cases, it is not possible to characterize a food poisoning outbreak by enumerating CPS in food remnants or a fortiori detecting se genes in isolated strains.

While S. aureus is classically enumerated using microbiological techniques with dedicated media such as Baird Parker or rabbit plasma fibrinogen agar media, three types of methods are usually performed to detect bacterial toxins in food: Bioassays, molecular biology and/or immunological techniques. 


\subsection{Bioassays}

Bioassays are based on the capacity of an extract of the suspected food to induce symptoms such as vomiting, gastrointestinal symptoms in animals and/or superantigenic action in cell cultures. Historically, SEs have been detected based on their emetic activity in monkey-feeding and kitten-intraperitoneal tests [28,29] and, more recently, using animal models such as house musk shrews Suncus murinus [14]. Symptoms of SFP appear if the dose ingested by the animals is above $200 \mathrm{ng}$, a considerably higher amount than those involved in human food poisoning [24-30]. Thus, this technique is not appropriate for characterizing SFPOs. More recently, a bioassay to detect the superantigenic activity of SEA has been developed [31]. This method uses SEA's superantigenic activity to induce in cytotoxic T lymphocytes a cytotoxic response against SEA-bound Raji cells. This test can only detect SEA at picomolar concentrations, and is thus of little interest for laboratories involved in official controls and SFP testings.

In conclusion, in addition to the fact that the use of laboratory animals for testing is now restricted for ethical reasons, bioassays are not sensitive enough to ensure food safety for consumers. Thus, alternative methods for detecting SEs have been developed.

\subsection{Molecular Tools}

Molecular biology methods often involve the polymerase chain reaction (PCR). These methods usually detect genes encoding enterotoxins in strains of $S$. aureus isolated from contaminated foods. However, these methods have two major limitations: first, staphylococcal strains must be isolated from food, and second, the results inform as to the presence or absence of genes encoding SEs, but do not provide any information on the expression of these genes in food. This method therefore cannot be the sole method to detect SEs in food. However, the PCR approach is a specific, highly sensitive, and rapid method that can characterize the $S$. aureus strains involved in SFPOs, thereby providing highly valuable information.

To improve SFP characterization, very recent efforts have been directed to determine which genes are involved in the biosynthesis of SEs. Following the huge SFP event which occurred in Japan in July 2000 (more than 13,000 people were intoxicated by powdered or liquid milk), Ikeda et al. [30] developed a PCR-based methodology whereby sea, seg, seh and sei genes could be detected in the incriminated powdered skim milk, although cultivable $S$. aureus were not recovered from the sample. Recently, to evaluate the toxic potential of strains isolated from SFPOs, various authors [32,33] have designed primers to perform PCR and reverse transcription PCR (RT-PCR) for se genes. These approaches demonstrate possible transcription of mRNA from those genes, but do not indicate whether those strains were able to produce detectable or poisonous levels of toxins in food. For example, Derzelle et al. [34] developed an RT-PCR-based procedure to determine the temporal expression of enterotoxin genes, including many of the newly discovered ones, in optimal growth conditions. PCR assays that can screen for 18 se genes have been developed and the distribution of these genes was examined on a panel of enterotoxigenic coagulase-positive staphylococci, including reference strains and isolates that have been collected from foods and SFPOs in France since the 1980s. A total of 
28 strains displaying multiple enterotoxin genotypes were selected for further mRNA expression kinetics studies.

More recently, Duquenne et al. [35] developed an efficient method to extract bacterial RNA accessible for RT-quantitative PCR (RT-qPCR) from cheese and adapted a simple, sensitive and reproducible, method for quantifying relative transcript levels to evaluate $S$. aureus enterotoxin gene expression during cheese manufacture.

\subsection{Immunological Tools}

The third and most commonly used method for detecting SEs in food is based on the use of anti-enterotoxin polyclonal or monoclonal antibodies. Commercially available kits have been developed according to two different principles: (1) enzyme immunoassay (EIA) comprising enzyme-linked immunosorbent assay (ELISA) and enzyme-linked fluorescent assay (ELFA); and (2) reverse passive latex agglutination (RPLA).

It is widely recognized that the use of immunological methods to detect contaminants in food matrices is a difficult task, mainly due to the lack of specificity and sensitivity of the assay. Many drawbacks impair the development and use of these techniques for detecting SEs. First, highly purified toxins are needed to raise specific antibodies to develop an EIA; purified toxins are difficult and expensive to obtain. Moreover, and until very recently, only antibodies against SEA to SEE, SEG, SEH and SElQ have been available [36]. The ELISA test will not detect the other SEs, which partly explains some discrepancies that have arisen in the analysis of food extracts from SFPOs. Another drawback is the low specificity of some marketed kits, where false positives may occur depending on food components $[37,38]$ as it is well known that some proteins, such as protein A, can interfere with binding to the Fc fragment (and, to a lesser extent, Fab fragments) in immunoglobins $\mathrm{G}$ from several animal species, such as mouse or rabbit, but not rat or goat. Other interferences are associated with endogenous enzymes, such as alkaline phosphatase or lactoperoxidase.

Whatever the detection method used and due to the low amount of SEs present in food, it is crucial to concentrate the extract before performing detection assays. For this purpose, various methodologies have been tested [39-41]. Among them, only extraction followed by dialysis concentration has been approved by the EU to extract SEs from food [42].

However, up to now, after enumerating CPS strains, conclusive diagnosis of SFPs has been mainly based on demonstrating the presence of SEs in food using commercial EIA kits designed to detect SEA to SEE $[43,44]$ or using a confirmatory in-house ELISA method [45] to differentiate and quantify these types of SEs.

\subsection{Chromatographic Methods for the Detection and Quantification of SEs}

Due to drawbacks and the lack of available antibodies against the newly described SEs, other strategies based on physico-chemical techniques have been developed. Among these, mass spectrometry (MS) has recently emerged as an indispensable and suitable technique to analyze protein and peptide mixtures [46]. It is among the most sensitive techniques currently available because it provides specific, rapid and reliable analytical results. The development of two soft ionization methods, such as electrospray ionization (ESI) and matrix-assisted laser desorption/ionization 
(MALDI), and the use of appropriate mass analyzers have revolutionized the analysis of biomolecules. Given the wide range of methodologies available, a single MS technique cannot be used for all proteins [and all purposes]. The MS method thus requires the development of a series of techniques, individually suited for each particular case.

In the case of food analysis, the situation is complex because the matrix can contain many proteins, lipids and many other molecular species that can interfere with the detection of the targeted toxin and may distort quantification. Sample preparation remains the critical step of the analysis. Several authors have tried to improve this step, by, for example, optimizing digestion parameters [47] or by adding a purification step [48]. The strategy of incorporating an isotopically labeled internal standard into the samples has also been developed. In the case of SE detection, some authors have developed MS tools to detect these toxins in culture supernatants and in spiked samples, such as water or apple juice. For example, Bernardo et al. [49] developed a MALDI-TOF method to detect $S$. aureus virulence factors such as enterotoxins and demonstrated that this technique was suitable for detecting SEs other than SEA to SEE in culture supernatants. In contrast, Callahan et al. [50] detected and quantified SEB using liquid chromatography coupled to ESI/MS detection in apple juice used as a model food matrix. In this study, enterotoxin types SEA and SEB were detected in spiked cheese. Recently, Brun et al. [51] developed an MS approach able to perform absolute quantification of SEA and TSST1 in spiked water or urine samples. To improve characterization and absolute quantification of SEs, this latter methodology was successfully used to carry out absolute quantification of SEA in a naturally contaminated cheese sample [52].

\section{An Integrated Approach to Improve SFPO Characterization}

To improve SFPO characterization, various techniques, such as immunological and molecular-based methodologies, have been integrated in the diagnosis strategy. The PCR approach is known to provide information on the presence or absence of genes encoding SEs, but not their expression. Nevertheless, PCR supplements classical methods, providing interesting additional data. In a study conducted on 178 S. aureus strains corresponding to 31 SFPOs isolated in France between 1981 and 2002, the results from a PCR assay revealed a satisfactory correlation (84\%) with the results from immunoassay methods [53].

Due to the satisfactory results obtained, in 2005, the EU Reference Laboratory (EU-RL) for CPS, decided to use the PCR procedure to improve SFPO characterization. The diagnosis of SFPO essentially based on SEs has been significantly strengthened. For example, very recently, PCR on se genes has been used to demonstrate for the first time the presence of CPS strains carrying the see gene and able to produce the SEE in unpasteurized cheeses involved in six outbreaks in France [54].

To complete SFPO characterization, MS tools have been also used in combination with those presented above. Thus, an overall approach combining microbiology, molecular, immunological and quantitative mass spectrometry techniques was successfully used for investigations of SEs content in cheese [52] or in a dessert involving in food poisoning outbreaks [55]. 


\section{Conclusions}

To conclude, an overall approach combining classical microbiology to enumerate CPS strains coupled with immunological techniques, molecular biology and mass spectrometry-based methods offers an interesting alternative for assigning outbreaks to SEs. Thus, the development of standards to perform absolute quantification will continue. While the quantitative MS method overpasses specific technical limitations of existing ELISA methods for detecting and quantifying SEs, its throughput and cost per analysis compares unfavorably with ELISA. For this reason, when the MS-based method becomes available for all SEs involved in SFPOs it will not be employed for routine analysis, but only in special cases to confirm outbreaks due to SEs.

\section{References}

1 Rosenbach, F.J. Microorganismen bei den Wund-Infections-Krankheiten des Menschen; Bergmann, J.F., Ed.; Wiesbaden, Germany, 1884; pp. 1-122.

2 De la Fuente, R.; Suarez, G.; Schleifer, K.H. Staphylococcus aureus subsp. Anaerobius subsp. nov., the causal agent of abscess disease of sheep. Int. J. Syst. Bacteriol. 1985, 35, 99-102.

3 Hajek, V. Staphylococcus intermedius, a New Species Isolated from Animals. Int. J. Syst. Bacteriol. 1976, 26, 401-408.

4 Devriese, L.A.; Hajek, K.; Oeding, P.; Meyer, S.A.; Schleifer, K.H. Staphylococcus hyicus (Sompolinsky 1953) comb. nov. and Staphylococcus hyicus subsp. chromogenes subsp. nov. Int. J. Syst. Bacteriol. 1978, 28, 482-490.

5 Varaldo, P.E.; Kilpper-Balz, R.; Biavasco, F.; Satta, G.; Scheifer, K.H. Staphylococcus delphini sp. nov., a coagulase-positive species isolated from dolphins. Int. J. Syst. Bacteriol. 1988, 38, 436-439.

6 Igimi, S.; Takahashi, E.; Mitsouka, T. Staphylococcus schleiferi subsp. coagulans subsp. nov., isolated from the external auditory meatus of dogs with external ear otitis. Int. J. Syst. Bacteriol. 1990, 40, 409-411.

7 Foster, G.; Ross, H.M.; Hutson, R.A.; Collins, M.D. Staphylococcus lutrae sp. nov., a new coagulase-positive species isolated from otters. Int. J. Syst. Bacteriol. 1997, 47, 724-726.

8 Balaban, N.; Rasooly, A. Staphylococcal enterotoxins. Int. J. Food Microbiol. 2000, 61, 1-10.

9 Orwin, P.M.; Leung, D.Y.; Donahue, H.L.; Novick, R.P.; Schlievert, P.M. Biochemical and Biological Properties of Staphylococcal Enterotoxin K. Infect. Immun. 2001, 69, 360-366.

10 Jarraud, S.; Peyrat, M.A.; Lim, A.; Tristan, A.; Bes, M.; Mougel, C.; Etienne, J.; Vandenesch, F.; Bonneville, M.; Lina, G. egc, a highly prevalent operon of enterotoxin gene, forms a putative nursery of superantigens in Staphylococcus aureus. J. Immunol. 2001, 166, 669-677.

11 Omoe, K.; Imanishi, K.; Hu, D.L.; Kato, H.; Fugane, Y.; Abe, Y.; Hamaoka, S.; Watanabe, Y.; Nakane, A.; Uchiyama, T.; Shinagawa, K. Characterization of novel staphylococcal enterotoxin-like toxin type P. Infect. Immun. 2005, 73, 5540-5546.

12 Orwin, P.M.; Leung, D.Y.M.; Tripp, T.J.; Bohach, G.A.; Earhart, C.A.; Ohlendorf, D.H.; Schlievert, P.M. Characterization of a novel staphylococcal enterotoxin-like superantigen, a member of the group V subfamily of pyrogenic toxins. Biochemistry 2002, 41, 14033-14040. 
13 Omoe, K.; Hu, D.L.; Takahashi-Omoe, H.; Nakane, A.; Shinagawa, K. Identification and characterization of a new staphylococcal enterotoxin-related putative toxin encoded by two kinds of plasmids. Infect. Immun. 2003, 71, 6088-6094.

14 Ono, H.K.; Omoe, K.; Imanishi, K.; Iwakabe, Y.; Hu, D.L.; Kato, H.; Saito, N.; Nakane, A.; Uchiyama, T.; Shinagawa, K. Identification and characterization of two novel staphylococcal enterotoxins types S and T. Infect. Immun. 2008, 76, 4999-5005.

15 Letertre, C.; Perelle, S.; Dilasser, F.; Fach, P. Identification of a new putative enterotoxin SEU encoded by the egc cluster of Staphylococcus aureus. J. Appl. Microbiol. 2003, 95, 38-43.

16 Thomas, D.Y.; Jarraud, S.; Lemercier, B.; Cozon, G.; Echasserieau, K.; Etienne, J.; Gougeon, M.L.; Lina, G.; Vandenesch, F. Staphylococcal enterotoxin-like toxins U2 and V, two new staphylococcal superantigens arising from recombination within the enterotoxin gene cluster. Infect. Immun. 2006, 74, 4724-4734.

17 Betley, M.J.; Mekalanos, J.J. Staphylococcal enterotoxin A is encoded by a phage. Science 1985, 229, 185-187.

18 Bayles, K.W.; Iandolo, J.J. Genetic and molecular analysis of gene encoding staphylococcal enterotoxin D. J. Bacteriol. 1989, 171, 4799-4806.

19 Yarwood, J.M; McCormick, J.K.; Paustian, M.L.; Orwin, P.M.; Kapur, V.; Schlievert, P.M. Characterization and expression analysis of Staphylococcus aureus pathogenicity island 3. Implications for the evolution of staphylococcal pathogenicity islands. Biol. Chem. 2002, 277, 13138-13147.

20 Papageorgiou, A.; Acharya, K. Microbial superantigens: from structure to function. Trends Microbiol. 2000, 8, 369-375.

21 Dinges, M.M.; Orwin, P.M.; Schlievert, P.M. Exotoxins of Staphylococcus aureus. Clin. Microbiol. Rev. 2000, 13, 16-34.

22 Papageorgiou, A.C.; Tranter, H.S.; Acharya, H.K. Crystal structure of microbial superantigen staphylococcal enterotoxin B at $1.5 \AA$ resolution: Implications for superantigen recognition by MHC class II molecules and T-cell receptors. J. Mol. Biol. 1998, 277, 61-79.

23 Jablonski, L.; Bohach, G.A. Staphylococcus aureus. In Food microbiology fundamentals and frontiers; Doyle, M.P., Beuchat, L.R., Montville, T.J., Eds.; America society of Microbiology Press: Washington, DC, USA, 2001; pp. 411-434.

24 Asao, T.; Kumeda, Y.; Kawai, T.; Shibata, T.; Oda, H.; Haruki, K.; Nakazawa, H.; Kozaki, S. An extensive outbreak of staphylococcal food poisoning due to low-fat milk in Japan: Estimation of enterotoxin $\mathrm{A}$ in the incriminated milk and powdered skim milk. Epidemiol. Infect. 2003, 130, 33-40.

25 Pereira, M.L.; Do Carmo, L.; Dos Santos, E.J.; Pereira, J.L.; Bergdoll, M.S. Enterotoxin H in staphylococcal food poisoning. J. Food Prot. 1996, 59, 559-561.

26 The Community Summary Report on Trends and Sources of Zoonoses, Zoonotic Agents and food-borne outbreaks in the European Union in 2008. EFSA J. 2010, 1496. Available online: http://www.efsa.europa.eu/en/scdocs/doc/s1496.pdf (accessed on 6 August 2010).

27 Bryan, F.L.; Guzewich, J.J.; Todd, E.C.D. Surveillance of foodborne disease II. Summary and presentation of descriptive data and epidemiologic patterns; their value and limitations. J. Food Prot. 1997, 60, 567-578. 
28 Surgalla, M.; Bergdoll, M.S.; Dack, G.M. Some observations on the assay of staphylococcal enterotoxin by the monkey feeding test. J. Lab. Clin. Med. 1953, 41, 782-788.

29 Bergdoll, M.S. Staphylococcal intoxications. In Food-borne Infections and Intoxications; Riemann, H., Bryan, F.L., Eds.; Academic press: New York, NY, USA, 1979; pp. 443-494.

30 Ikeda, T.; Tamate, N.; Yamaguchi, K.; Makino, S. Mass outbreak of food poisoning disease caused by small amounts of staphylococcal enterotoxins A and H. Appl. Environ. Microbiol. 2005, 71, 2793-2795.

31 Hawryluk, T.; Hirshfield, I. A super antigen bioassay to detect staphylococcal enterotoxin A. J. Food Prot. 2002, 65, 1183-1187.

32 Lee, Y.D.; Moon, B.Y.; Park, J.H.; Chang, H.I.; Kim, W.J. Expression of enterotoxin genes in Staphylococcus aureus isolates based on mRNA analysis. J. Microbiol. Biotechnol. 2007, 17, 461-467.

33 Akineden, O.; Hassan, A.A.; Schneider, E.; Usleber, E. Enterotoxigenic properties of Staphylococcus aureus isolated from goats' milk cheese. Int. J. Food Microbiol. 2008, 124, 211-216.

34 Derzelle, S.; Dilasser, F.; Duquenne, M.; Deperrois, V. Differential temporal expression of the staphylococcal enterotoxins genes during cell growth. Food Microbiol. 2009, 26, 896-904.

35 Duquenne, M.; Fleurot, I.; Aigle, M.; Darrigo, C.; Borezée-Dupont, E.; Derzelle, S.; Bouix, M.; Deperrois-Lafarge, V.; Delacroix-Buchet, A. Tool for Quantification of Staphylococcal Enterotoxin Gene Expression in Cheese. Appl. Environ. Microbiol. 2010, 76, 1367-1374.

36 Schlievert, P.M.; Case, L.C. Molecular analysis of staphylococcal superantigens. Methods Mol. Biol. 2007, 391, 113-126.

37 Park, C.E.; Akhtar, M. Rayman, M.K. Nonspecific reactions of a commercial enzyme-linked immunosorbent assay kit (TECRA) for detection of staphylococcal enterotoxins in foods. Appl. Environ. Microbiol. 1992, 58, 2509-2512.

38 Wieneke, A.A. Comparison of four kits for the detection of staphylococcal enterotoxin in foods from outbreaks of food poisoning. Int. J. Food Microbiol. 1991, 14, 305-312.

39 Macaluso, L.; Lapeyre, C.; Dragacci, S. Determination of influential factors during sample preparation for staphylococcal enterotoxin detection in dairy products. Analusis 1998, 26, 300-304.

40 Meyrand, A.; Atrache, V.; Bavai, C.; Montet, M.P.; Vernozy-Rozand, C. Evaluation of an alternative extraction procedure for enterotoxin determination in dairy products. Lett. Appl. Microbiol. 1999, 28, 411-415.

41 Lapeyre, C.; Maire, T.; Messio, S.; Dragacci, S. Enzyme immunoassay of staphylococcal enterotoxins in dairy products with cleanup and concentration by immunoaffinity column. J. AOAC Int. 2001, 84, 1587-1592.

42 European Community. Commission Regulation. No. 1441/2007 of 5 December 2007. Off. J. Eur. Union. 2007, L322, 12-29.

43 Bennett, R.W. Staphylococcal enterotoxin and its rapid identification in foods by enzyme-linked immunosorbent assay-based methodology. J. Food Prot. 2005, 68, 1264-1270.

44 Hennekinne, J.A.; Ostyn, A.; Guillier, F.; Gohier, M.; Messio, S.; Dragacci, S.; Krys, S.; Lombard, B. Interlaboratory validation of the Vidas SET2 detection kit for an use in official 
controls of staphylococcal enterotoxins detection in milk products especially low-fat cheeses. J. AOAC Int. 2007, 90, 756-764.

45 Lapeyre, C.; Janin, F.; Kaveri, S.V. Indirect double sandwich ELISA using monoclonal antibodies for detection of staphylococcal enterotoxins A, B, $\mathrm{C}_{1}$ and D in food samples. Food Microbiol. 1988, 5, 25-31.

46 Mamone, G.; Picariello, S.; Caira, F.; Addeo, P. Ferranti, P. Analysis of food proteins and peptides by mass spectrometry based techniques. J. Chromatogr. A 2009, 1216, 7130-7142.

47 Norrgran, J.; Williams, T.L.; Woolfitt, A.R.; Solano, M.I.; Pirkle, J.L.; Barr, J.R. Optimization of digestion parameters for protein quantification. Anal. Biochem. 2009, 393, 48-55.

48 Oeljeklaus, S.; Meyer, H.E.; Warscheid, B. New dimensions in the study of protein complexes using quantitative mass spectrometry. FEBS Lett. 2009, 583, 1674-1683.

49 Bernardo, K.; Pakulat, N.; Macht, M.; Krut, O.; Seifert, H.; Fleer, S.; Hunger F.; Kronke, M. Identification and discrimination of Staphylococcus aureus strains using matrix-assisted laser desorption/ionization-time of flight mass spectrometry. Proteomics 2002, 2, 747-753.

50 Callahan, J.H.; Shefcheck, K.J.; Williams, T.L.; Musser, S.M. Detection, confirmation, and quantification of staphylococcal enterotoxin B in food matrixes using liquid chromatography-mass spectrometry. Anal. Chem. 2006, 78, 1789-1800.

51 Brun, V.; Dupuis, A.; Adrait, A.; Marcellin, M.; Thomas, D.; Court, M.; Vandenesch, F.; Garin, J. Isotope-labeled protein standards: toward absolute quantitative proteomics. Mol. Cell Proteomics 2007, 6, 2139-2149.

52 Dupuis, A.; Hennekinne, J.A.; Garin, J.; Brun, V. Protein Standard Absolute Quantification (PSAQ) for improved investigation of staphylococcal food poisoning outbreaks. Proteomics 2008, 8, 4633-4636.

53 Kerouanton, A.; Hennekinne, J.A.; Letertre, C.; Petit, L.; Chesneau, O.; Brisabois, A.; De Buyser, M.L. Characterization of Staphylococcus aureus strains associated with food poisoning outbreaks in France. Int. J. Food Microbiol. 2007, 115, 369-375.

54 Ostyn, A.; De Buyser, M.L.; Guillier, F.; Groult, J.; Félix, B.; Salah, S.; Delmas, G.; Hennekinne, J.A. First evidence of a food poisoning outbreak due to staphylococcal enterotoxin type E, France, 2009. EuroSurveillance 2010, 15, 19528. Available online: http://www.eurosurveillance.org/ ViewArticle.aspx?ArticleId=19528 (accessed on 13 July 2010).

55 Hennekinne, J.A.; Brun, V.; De Buyser, M.L.; Dupuis, A.; Ostyn, A.; Dragacci, S. Innovative contribution of mass spectrometry to characterise staphylococcal enterotoxins involved in food outbreaks. Appl. Environ. Microbiol. 2009, 75, 882-884.

(C) 2010 by the authors; licensee MDPI, Basel, Switzerland. This article is an Open Access article distributed under the terms and conditions of the Creative Commons Attribution license (http://creativecommons.org/licenses/by/3.0/). 